\title{
TECHNOLOGIES OF EXPOSING THE VALANGIAN DEPOSITS
}

• . ник ровский, . . ник ровский

E. V. Panikarovski, V. V. Panikarovski

юменский индустри льный университет, г. юмень

лючевые слов : поглощение бурового р створ ; бурильный инструмент; вскрытие пл стов Key words: drilling mud losses; drilling tool; formation exposure

ля р зр ботки г зоконденс тных з лежей ренгойского месторождения предусм трив ется строительство пологих, горизонт льных и н клонно н пр вленных скв жин.

пологих и горизонт льных скв жин отклонение от вертик ли по кровле пл ст сост вляет от 1000 до 2000 м, протяженность ствол по пл сту сост вляет $600 \mathrm{м.}$ тклонение от вертик ли д нных скв жин по объект м эксплу т ции определяется исходя из прочности бурильного инструмент под действием усилий р стяжения, сж тия, изгиб , кручения и совместного их действия, т кже проходимости по стволу 
скв жины обс дных колонн, их прочности под действием возник ющих н грузок и герметичности резьбовых соединений.

ля успешной ре лиз ции технологий строительств скв жин с большими отклонениями от вертик ли в условиях ренгойского месторождения возник ет необходимость использов ния буровых уст новок грузоподъемностью более 500 т, п рк которых в н стоящее время огр ничен в связи с освоением чимовских 3 лежей.

троительство скв жин с отклонением от вертик ли более 2000 м для в л нжинских пл стов требует применения технологий спуск обс дных колонн с ч стичным опорожнением, ре лиз ция которых возможн с привлечением для бурения скв жин з рубежных сервисных комп ний, что может привести к удорож нию строительств скв жин.

р метры отклонения профилей ствол скв жины от вертик ли з висят от длины вертик льного уч стк, условий вскрытия пл стов, регулируются величиной н ч льного зенитного угл и длиной уч стк ст билиз ции п р метров кривизны.

ля предупреждения осложнений в процессе спуск обс дных колонн и н рушений герметичности резьбовых соединений применяют м ксим льную интенсивность искривления скв жин при спуске промежуточной колонны ди метром 245 мм и эксплу т ционной колонны ди метром 168 мм, котор я сост вляет 1\%10 м.

ехническим решением для освоения в л нжинских 3 лежей является строительство эксплу т ционных скв жин с горизонт льным и вертик льным оконч нием, т кже применение конструкций скв жин с использов нием открытого и з крытого 3 боя. ксплу т цию объектов с открытым з боем можно проводить с помощью фильтр производств « яжпромм ш».

ротяженность ствол скв жин с пологим или горизонт льным оконч нием, оборудов нных фильтром, сост вляет 600 м.

онструкция скв жин с открытым з боем предусм трив ет спуск кондуктор ди метром 324 мм, промежуточной колонны диметром 245 мм, эксплу т ционной колонны ди метром 168 мм, фильтр -хвостовик ди метром 114 мм в продуктивную ч сть пл ст . лубин спуск промежуточной колонны определяется необходимостью перекрытия верхней ч сти сеном нского горизонт и сост вляет 1350 м по вертик ли. ксплу т ционн я колонн спуск ется в кровлю продуктивного пл ст, фильтрхвостовик крепится к эксплу т ционной колонне с помощью подвесного устройств , что позволяет проводить промывку фильтр и з боя скв жины.

онструкция скв жин с з крытым з боем предусм трив ет спуск эксплу т ционной колонны ди метром 168 мм, цементиров ние с последующей перфор цией в интерв ле продуктивного пл ст . ементиров ние эксплу т ционной колонны проводят прямым способом с 3 к чкой цементного р створ с з боя до б шм к промежуточной

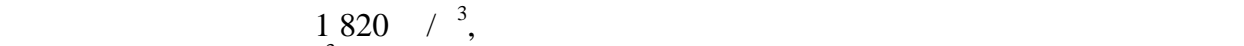
плотностью $1400 \mathrm{Kг} / \mathrm{M}^{3}$.

ри освоении скв жин с открытым з боем 3 меняют технологический р створ в скв жине н г зоконденс т или нефть плотностью от 774 до 830 кг/м³ . целью получения н иболее эффективной очистки интерв л продуктивного пл ст проводится промывк фильтр и з боя скв жины с помощью колтюбинговой уст новки для пуск скв жины в р боту по трубному простр нству.

своение скв жины с 3 крытым з боем проводится после проведения вторичного вскрытия. торичное вскрытие осуществляется перфор тор ми с повышенной пробивной способностью тип Power Jot 2906, Power Jot 2306 и др., сборк ми до 50 м. своение скв жины н чин ется с $з$ мены бурового р створ н солевой р створ плотностью 1140 кг/м³ после двух циклов промывки.

ля восст новления эксплу т ционного фонд скв жин, вскрывших в л нжинские отложения, проводится бурение боковых стволов. лубину р сположения окн для бурения бокового ствол выбир ют исходя из геологического р зрез горных пород. орные породы должны обл д ть устойчивостью, коэффициент к вернозности не должен превыш ть 1,1 и должны отсутствов ть ном льные пл стовое и поровое д вления [1].

основ нии тр ектории ст рого ствол скв жины и координ т точки вход в пл ст нового бокового ствол уст н влив ют р сположение уч стков изменения зенитного угл и зимут вход в пл ст бокового ствол . ри проведении этих р бот 
следует учитыв ть н личие в р зрезе интерв лов горных пород, склонных к обв лооб$\mathrm{p}$ зов нию и поглощению бурового р створ .

рофили боковых стволов проектируются для к ждой скв жины с учетом ф ктической тр ектории пробуренной скв жины и новой точки вход ствол в пл ст.

н лиз ф ктических профилей пробуренных скв жин и рекоменд ции по изменению положения з боя скв жин позволяют применять следующие профили боковых стволов: профили плоского тип, когд бурение осуществляется из вертик льных и н клонных скв жин, координ ты з боя совп д ют с зимут льным н пр влением; профиль простр нственного тип, когд бурение бокового ствол проводится из н клонной скв жины, координ ты з боя не совп д ют с зимут льным н пр влением нового з боя.

ффективность бурения скв жин определяется выбором бурильного инструмент и геолого-техническими условиями бурения скв жины.

процессе строительств бокового ствол для ориентиров ния в сост в бурильного инструмент включ ются телеметрические системы, которые должны обеспечив ть перед чу информ ции с з боя в ре льном времени и позволять вр щ ть бурильную колонну. ри бурении интерв лов под хвостовик д нные телесистемы должны обеспечив ть р боты по промывке скв жины облегченным р створом. н стоящее время для проведения этих р бот рекомендуются телесистемы 3 -42 отечественного производств .

ри бурении боковых стволов в в л нжинских отложениях вскрытие их может проводиться в зон х с ном льно высокими поровыми д влениями ( ) с коэффициентом ном льности от 1,11 до 1,30 и зон х с ном льно низкими пл стовыми д влениями ( ) с коэффициентом ном льности от 0,53 до 0,74 .

ервое условие определяет вскрытие глинистых пл стов, где с целью предотвр щения обв лообр зов ния рекомендуют буровые $р$ створы плотностью $1160 \mathrm{Kr} / \mathrm{M}^{3}$.

торое условие определяет ликвид цию поглощений бурового р створ в зон х , которое соблюд ется при применении р створов плотностью от 1205 до $1270 \mathrm{Kг} / \mathrm{M}^{3}$ (т бл. 1 ).

лотность бурового р створ при строительстве боковых стволов

\begin{tabular}{|c|c|c|}
\hline \multirow{2}{*}{ есторождение, пл ст } & \multicolumn{2}{|c|}{ лотность бурового р створ , кг/м для условий } \\
\cline { 2 - 3 } & $\begin{array}{c}\text { ликвид ции г зопроявлений и } \\
\text { обв лообр зов ний }\end{array}$ & эффективного вскрытия пл стов \\
\hline ренгойское & 1160 & - \\
«шокол дные» глины & - & 680 \\
$8-99$ & - & 650 \\
$10-\quad 14$ & & \\
\hline
\end{tabular}

скрытие в л нжинских отложений требует применения в сост ве бурового р створ кольм тирующих н полнителей, способствующих з купорив нию трещин в н ч льной ст дии их обр зов ния. ля этих целей при бурении скв жин рекомендуется использов ть кольм т нты ик н-40, ил нж.

ри применении буровых р створов н водной основе для снижения проникновения водного фильтр т в сост в р створ вводят ре генты с ингибирующими свойств ми: ольм сил и др. ольм сил содержит в своем сост ве силик т н трия, углещелочной ре гент, триполифосф т н трия, борную кислоту.

ля эффективного вскрытия продуктивных пл стов с требуется применение бурового р створ плотностью меньше $750 \mathrm{kr} / \mathrm{M}^{3}$. ешение этой проблемы связ но с применением для бурения скв жин эриров нных р створов. омпонентный сост в бурового р створ приведен в т блице 2 . ервон ч льн я плотность бурового р ство$\mathrm{p}$, сост вляющ я $1100 \mathrm{Kг} / \mathrm{m}^{3}$, был снижен до $700 \mathrm{Kг} / \mathrm{m}^{3}$. 
омпонентный сост в эриров нного бурового р створ

\begin{tabular}{|c|c|c|}
\hline $\begin{array}{r}\text { именов ние } \\
\text { химре гентов }\end{array}$ & ель применения бурового р створ & $\begin{array}{c}\text { сход ре гентов, } \\
\text { Кг }\left(100 \mathrm{~m}^{3} \text { р створ }\right)\end{array}$ \\
\hline $\begin{array}{l}\text { линопорошок } \\
\text { бентонитовый }\end{array}$ & $\begin{array}{c}\text { риготовление глинистой суспензии, } \\
\text { формиров ние фильтр ционной корки }\end{array}$ & 12000 \\
\hline-700 (Tylose) & $\begin{array}{c}\text { егулиров ние реологических } \\
\text { и фильтр ционных свойств р створ }\end{array}$ & $250-300$ \\
\hline $\begin{array}{r}\text { мыленный } \\
\text { т ловый пек } \\
\end{array}$ & $\begin{array}{l}\text { егулиров ние поверхностного н тяжения } \\
\text { для эмульгиров ния пор коллектор }\end{array}$ & $300-600$ \\
\hline $\begin{array}{l}\text { р морн я крошк } \\
\text { мелкодисперсн я }\end{array}$ & $\begin{array}{l}\text { ислотор створимый кольм т нт } \\
\text { для блокиров ния пор коллектор }\end{array}$ & $2000-3000$ \\
\hline $\begin{array}{l}\text { риполифосф т } \\
\text { (нитротриметилфосфонов я } \\
\text { кислот ) }\end{array}$ & $\begin{array}{l}\text { нижение вязкости бурового р створ , } \\
\text { нейтр лиз ция ионов К льция }\end{array}$ & $10-15$ \\
\hline еног ситель & $\begin{array}{l}\text { ля обеспечения к честв р створ при } \\
\text { проведении . овышение плотности } \\
\text { р створ при потере устойчивости стенок } \\
\text { скв жины } \\
\end{array}$ & $150-200$ \\
\hline
\end{tabular}

ругим н пр влением повышения к честв вскрытия пл стов является применение $\mathrm{p}$ створов н углеводородной основе ( ). пыт применения $\mathrm{H}$ ренгойском и мбургском месторождениях пок з л, что при вскрытии пл стов с зн чительное время тр тится н ликвид цию поглощений р створов продуктивными пл ст ми, хотя позволяют сохр нить фильтр ционные х р ктеристики пород и сниж ют в рийность проведения буровых р бот.

дним из перспективных н пр влений вскрытия продуктивных пл стов является вскрытие их н депрессии, которое обеспечив ет получение более высоких дебитов и увеличив ет добычу углеводородов.

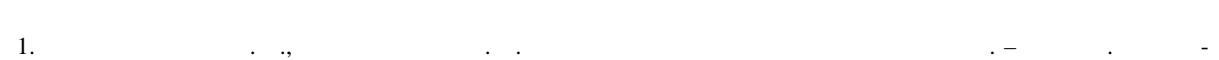
, 2012. - 126c.

\section{ведения об втор $x$}

ник ровский вгений лентинович, т. н., доцент к федры « урение нефтяных и г зовых скв жин», юменский индустри льный университет, г. юмень, тел. 8(3452)286697, e-mail: Panikarovskiy@tngg.ru

\section{ник ровский лентин сильевич,} д. т. н., профессор к федры « зр ботк и эксплу $m$ иия нефтяных и г зовых месторождений», юменский индустри льный университет, 2. юмень, тел. 8(3452)305700

\section{Information about the authors}

Panikarovski E. V., Candidate of Science in Engineering, associate professor of the chair «Drilling of oil and gas wells», Industrial University of Tyumen, phone: 8(3452)286697

Panikarovski V. V., Doctor of Engineering, professor of the chair "Drilling of oil and gas wells», Industrial University of Tyumen, phone: 8(3452)305700 